\title{
FUNDAMENTAL RIGHTS - THEIR REVOLUTION AND COMPARISON WITH DIRECTIVE PRINCIPLES OF STATE POLICY
}

\author{
Prof K Chandrashekhar \\ Dept of Post Graduate Studies and Research in Political Science, Kuvempu University, Shakaraghatta- \\ 577451 Shivamogga district
}

DOI: 10.46609/IJSSER.2021.v06i03.022 URL: https://doi.org/10.46609/IJSSER.2021.v06i03.022

\begin{abstract}
A study of the evolution of fundamental rights under the constitution of India can only be made by making a survey of the Constitutional History of India. The Britishers who set their feet on the Indian soil as traders ultimately colonised India and became its Imperial Master by 1858 . The centralisation of power which started with the Regulating Act of 1773 found its culmination in the charter Act of 1833.

The first war of Indian independence, historically dubbed as 'Sepoy Mutiny' represented the growing discontent against executive tyranny. This resulted in Queen Victoria's proclamation of 1058 and from then started the era of decentralisation through a series of Government of India Acts like those of 1909 (Morley-Minto Reforms), and 1919 (Montagu-Chelms for Reforms) and Government of India Act of 1935 based upon the deliberations of three Round Table conferences and the Indian Independence Act of 1947.
\end{abstract}

Key Words: Fundamental Rights, Directive Principles of State Policy, Preamble, Justice, Liberty, Equality, Fraternity, Welfare State Ideology, Socio-Economic Justice, Court of Law, Supreme Court of India.

\section{Introduction}

It was almost decided by 1946 that India was to get her independence and Indians would frame a constitution of their own. It is appropriate here to make a brief survey of historic struggle for freedom from 1857 to 1947. Indian National congress was established in 1885 by A.O. Hume. This was dedicated to the cause of freedom. It started with moderates and liberals. But by the turn of the twentieth century, there were conspicuous extremists like Bal Gangadhar Tilak who roared that Freedom was his birth right and that he should have it. While the moderates advocated a gradual evolution towards freedom by peaceful means, the extremists wanted to 


\section{International Journal of Social Science and Economic Research}

ISSN: $2455-8834$

Volume:06, Issue:03 "March 2021"

achieve it by revolution. Thetrial of Balgangadhar Tilak and his conviction made matters worse. The executive hold over the administration tightened and policy of oppression was adopted to suppress the democratic movement.Eminent Indians who had their liberal education in England, were at the forefront of the struggle for freedom. The most conspicuous amongst them was Mohandas Karmachand Gandhi, the young barrister who had just them returned from Union of south Africa. Gandhi is a central figure around whom is woven the historic struggle for freedom. It was to his lot to take the reins of leadership. By then senior politicians like Tilak, Gokhale and Ranade had died. Gandhi with his philosophy of Non- violence (Ahimsa) and truth launched a peaceful agitation. Despite Gandhi, Indian National congress continued to have in it a considerable group of extremists like Babu Subhash Chandra Bose and Lala Lajpat Roy. But Gandhi, as a dominant figure contained them effectively by mobilising around him great personalities like Dr. Rajendra Prasad, Rajaji, Jawaharlal Nehru, Sardar Patel, Maulana Azad,. The extremists were decisively in a minority. But their impact on the freedom movement was considerable and significant. In between the moderates and the extremists, were the liberals under thereadership of Right Hon'ble Srinivasa Shastri.

The Britishers tried to put down the freedom movement with an iron hand by restraining the press through licensing, prior censorship and confiscation for violation. Freedom of speech and expression, freedom of assembly and freedom of movement were restrained through laws and ordinances. The Jallianwallahbaag Tragedy, the humiliating Crawling order of Amritsar, the execution of extremistslike Chandrasekar Azad, Bhagat Singh and Dhingra, the imprisonment of national leaders who led the congress are the noteworthy landmarks of the great freedom movement. People underwent untoldsuffering and sacrifice for the great cause, and it would be untruthful to say that it was a bloodless and peaceful revolution. Gandhi was a tower of strength with his weapons of 'satyagraha', 'non- cooperation' and 'civil disobedience'. His enchanting hold over the masses was unprecedented. He was an astute politician with a saintly fervour. He combined in him the religious traditions of the east and the liberal traditions of the west. Ultimately, he led the nation to freedom and liberation.

It is appropriate to mention now about the elections held all over the Country during 1946-47 to elect members to the Constituent Assembly which was to frame a written constitution for India. constituent Assembly was formed in such a manner as to represent all sections of the people. Despite non- cooperation by the Muslim League, it went ahead with its task of framing a constitution under the chairmanship of Dr. Rajendra Prasad, Dr. Baba Saheb Ambedkar as chairman of the Drafting committee did a memorable job in improvising upon Sir. B.N.Rao's draft. ultimately the constituent Assembly finished its task by the end of November 1949 and the constitution came into force from the $26^{\text {th }}$ day of January 1950. 


\section{International Journal of Social Science and Economic Research}

ISSN: $2455-8834$

Volume:06, Issue:03 "March 2021"

The constitution of India is based on the four great pillars enunciated in the Preamble-justice, liberty, equality, and fraternity. Part III provides for fundamental rights while Part IV enunciates the Great Directive Principles which symbolise the goal towards a socialist welfare state. A blending of freedom with restraint, rights with duties appears to be the basic philosophy.

\section{COMPARATTVE ASSESSMENT WITH DIRECTIVE PRINCIPLES}

Fundamental rights are enunciated in Part-III of the Constitution of India. They are justiciable. That means, a citizen can enforce these rights before a court of Law. The right to enforce these rights by way of writs before the Supreme Court of India is itself a fundamental right under Article 32 of fundamental right under Article 32 of the Constitution. This is a distinctive feature of the Constitutionof India.

The fundamental right to equality of status and of opportunity, is subject to reasonable classification. The seven fundamental freedoms provided under Article 19 are all subject to reasonable restrictions. The freedom to practise any religion is there for all the citizens of India. But the state, as such, does not profess any religion and that is the secular ideology enshrined in the Constitution. The right to property is no longer a fundamental right and the minorities are conferred their educational rights.

The 'Directive Principles' enunciated in part IV of the constitution of India reflect the welfare state ideology and tries to achieve socio-economic justice by making these principles fundamental in the governance of the state. But the directive principles are non-justifiable, in the sense, they cannot be enforced before a court of Law. The reason is obvious because it involves lot of expenditure on the part of the state. unless we produce more wealth, we will not be able to translate into action the great ideals enshrined in part-IV. Old-age pensions, unemployment allowances, medical coverage for all, improvement of the conditions of labour, improvement of our environment, legal aid for the poor aresome of the highlights of the Directive Principles.

There was a time when our supreme court considered the fundamental rights superior to the directive principles and subsequently the position changed with greater emphasis on directive principles. our supreme court has never lagged in enforcing all such legislations which uphold the Directive Principles. For example, the land reforms legislations of various states could be cited.

It should be realised that no fundamental right would be worth its name if the directive principles could not be achieved. It is only when the stomach is full, a man starts contemplating over his rights. A hungry stomach needs no rights. Hence, I am of the conviction that the fundamental rights and directive principles are mutually complimentary and any controversy over the primacy 


\section{International Journal of Social Science and Economic Research}

ISSN: $2455-8834$

Volume:06, Issue:03 "March 2021"

is a meaningless dialogue.

The most interesting drama on the constitutional plane was enacted when parliament tried to amend the fundamental rights enunciated in part III of the constitution. I am now discussing the position prior to the 25 th Amendment to the Constitution.

Article 13(2) of part III clearly stated, "No law passed by the central or State legislature shall be validif it contravenes the provisions enunciated in part III of the constitution" (1).

The Crucial question that arose was this- Is the amendment to the Constitution itself by the parliament"Law' so as to attract the attention of Art 13(2)?.

In Shankari Prasad's case and Sajjan Singh's case our Supreme Court declared such an amendment is not 'law' as contained in Article 13(2). The court held that any amendment made in exercise of the 'Constituent Power' is not 'law'. Hence it does not attract the attention of Article 13(2) and as a logical consequence, the question of its unconstitutionality does not arise ${ }^{(2)}$.

But when the same question was raised in the famous Golaknath-case, ${ }^{(3)}$ Justice K. Subba Rao who the chief Justice was, speaking for the majority held a contrary opinion. The court held that there is no such thing as a 'Constituent Power' in the parliament. The only power which parliament has, is the legislative power. More so there is no 'power' to amend under Article 368, since its marginal noteonly states "Procedure for amendment". Wherein is the 'Power' to amend contained? It can only be in the legislative power under Articles 245 to 255. So, the Court held that any amendment in exercise of legislative power is 'law' and it comes within the ambit of the word 'Law' contained in Article 13(2). If it violates the fundamental rights, it will be unconstitutional. But did the court strike down the East Punjab land legislation unconstitutional? It did not. The reason was, by declaring all such amendments violating fundamental rights so far made unconstitutional from 1950-1965, it would lead to chaos and confusion and cause the greatest embarrassment to the executive. So, the court used theAmerican doctrine of 'prospective over-ruling' and declared that all amendments made so far are valid. But the parliament in future should keep its hands off the fundamental rights. In case it was todo so, the court would over-rule it as unconstitutional. It is this warning which rubbed the parliament on the wrong side. Parliament, with vengeance, amended article 368, Art 13[2] and got for it the power to amend any part of the constitution including Part III. This was virtually slap on the face of the judiciary.

Subsequently when the same question arose in the historic case Keshavananda_Bharathi, ${ }^{(4)}$ the Supreme Court conceded the power of the parliament but declared that such an amendment would be unconstitutional if it affects the basic structure of our Constitution. The subsequent $42^{\text {nd }}$ and $44^{\text {th }}$ Amendments even brushed aside this 'basic structure' dictum by declaring the parliament all 
International Journal of Social Science and Economic Research

ISSN: 2455-8834

Volume:06, Issue:03 "March 2021"

powerful. It was virtually an unfortunate confrontation between the parliament and the supreme court.But when the same issue came up again in the Minerva Mills case ${ }^{(5)}$ the court reasserted its dictum in Keshavananda Bharathi.

But it is unquestionable today that parliament has the power to amend any part of the Constitution. After everything said and done it should be remembered that while part III reflects the laissez faireideology, part IV reflects the welfare state concept of $20^{\text {th }}$ century. The question of superiority should not be so much exaggerated to spoil the harmonious balance between the two. More so judiciary, legislature and executive are the three vital organs of the administration and all of them are equallyimportant.

\section{Conclusion}

In respect of Keshavananda Bharathi case the basic structure theory was invented by Supreme Court and the same was reiterated on Minerva Mill Case. The salient features of the basic structure theory are briefly summarised below.

Abrogation of Fundamental rights by the parliament in exercising the amending power. No responsible leader ever suggested in constituent assembly, that in the exercise of amending power of the parliament, fundamental rights could be abrogated. A reading of the constituent assembly debatesleaves no doubt that if the leaders have provided for abrogation of fundamental rights, by parliament in the exercising of amending power, large sections of the people could have never agreed to accept the Constitution. We must be proud of eminent intellectuals like Dr. B R Ambedkar, Dr. Radhakrishnan, Dr. DadabaiNavaroji, SardarVallabai Patel and Mr. Pandit Nehru. The salientfeatures of the e Basic Structure theory are briefly summarised below.

1. Supremacy of the constitution. Sovereign Democratic and Republican nature of the Indian Polity.

2. Secular character of the Indian Polity. Separation of powers between the Legislative, Executive and Judiciary. Federal character of the constitution Unity and Integrity of the nation.

3. Welfare state (social and economic justice)

4. Judicial review.

5. Freedom and Dignity of the individual.

6. Rule of law. 
International Journal of Social Science and Economic Research

ISSN: 2455-8834

Volume:06, Issue:03 "March 2021"

7. Parliamentary system.

8. Harmony and balance between Fundamental rights and Directive principles.

9. Principle of Equality.

10. Free and fair elections.

11. Independence of the Judiciary.

12. Reasonable restrictions.

13. Effective access to justice.

14. Limited power of amending the constitution.

Thus, Article 31B deals with validation of certain acts and regulations. None of the acts and regulations specified in the ninth schedule nor any one of the provisions there of shall be deemed tobe wide on the ground that such acts ad regulations take away the rights. 284 invalid laws have been given protection through the process of validation.

\section{Footnotes and References}

1. Shankari Prasad Singh Dev and others versus Union of India - First Amendment Act declared as Intra Vires and constitution. AIR 1951 SC 458 1951RD(BR) 219-64 MLW 10051951 All India Law Journal page 740, Author - R G Chaturvedi III edition, Law Book Company, Allahabad, 1985page no 740

2. The Constitutional 17th Amendment of 1964 declared as Ultra Vires. And the decision of a Shankari Prasad versus Union of India and Sajjan Singh versus Rajasthan were overruled (AIR 1965 SC 845 All India Law Journal page 740, Author - R G Chaturvedi III edition, Law Book Company, Allahabad, 1985 page no 38)

3. Goloknath case, Constitutional 17th Amendment Act, 1964 was challenged in respect of Goloknath and others versus of state of Punjab case. AIR 1965 SC 845 All India Law Journal page 740, Author - R G Chaturvedi III edition, Law Book Company, Allahabad, 1985

4. Keshavananda Bharathi case AIR 1973 SC 1461 All India Law Journal page 740, Author - R GChaturvedi III edition, Law Book Company, Allahabad, 1985 
International Journal of Social Science and Economic Research

ISSN: 2455-8834

Volume:06, Issue:03 "March 2021"

5. Minarva Mill versus Union of India, AIR 1980 SC 1787 All India Law Journal page 740, Author - R G Chaturvedi III edition, Law Book Company, Allahabad, 1985 